\title{
Growth Curves of Texel Male Lambs
}

\author{
Michelli de Fatima Sieklicki', Victor Breno Pedrosa', Caroline Gomes Rocha', Raphael Patrick Moreira', \\ Paula Roberta Falcão', Izaltino Cordeiro dos Santos' ${ }^{2}$, Evandro Maia Ferreira' \& Adriana de Souza Martins'
}

\begin{abstract}
Background: The consumption of lamb meat is growing due to improved farming methods. However, to be economically feasible, the animal should stand out for its precocity, fast finishing and muscular force, such as seen in Texel breed. Besides, knowledge about weight gain and development can facilitate the selection of the best animals, and allow a better fitting to farming systems. Growth curves are an effective method that describes animal development, modeling the relationship between weight and age and help to predict the growth rate. Thus, this study aimed to analyze which nonlinear model, including Brody, Gompertz, Von Bertalanffy and Logistic best describe the growth curve of Texel sheep.

Materials, Methods \& Results: In this experiment, the lambs were kept in confined system while the ewes, in a semi-extensive system. This study followed 42 Texel male lambs, which were confined from birth to slaughter, and fed concentrated feed (3\% of body weight) and corn silage (average $1.5 \mathrm{~kg} / \mathrm{animal} / \mathrm{day}$ ), 4 times a day. The lambs were weighed fortnightly, in different classes considered as follows, weight at birth (BW), 15 days (P15), 30 days (P30), 45 days (P45), 60 days (P60), 75 days (P75), 90 days (P90), 105 days (P105), and 120 days (P120), which was defined as the slaughtering weight. The growth curves were determined using the nonlinear models of Brody, Von Bertalanffy, Gompertz and Logistic. The following parameters were used in the curves, $\mathrm{Y}$, slaughtering weight; A, asymptotic weight; $\mathrm{k}$, growth rate, $\mathrm{t}$, animal age; $\mathrm{B}$, constant related to the initial weight; and, $\mathrm{m}$, constant of the curve shape. The criteria used for selecting the model that best described the curve were the mean square error (MSE), which was calculated by dividing the sum of squared error by the number of observations, and also the coefficient of determination $\left(\mathrm{R}^{2}\right)$, calculated as the square of the correlation between the observed and estimated weights. The average weights observed were as follows, $4.02 \mathrm{~kg}$ at birth, $21.68 \mathrm{~kg}$ at weaning (P60) and $32.55 \mathrm{~kg}$ at slaughtering (P120). The solution of the nonlinear models allows, thru the parameters, establish specific feeding programs and define the optimal slaughtering age. Furthermore, the coefficients of determination, with values close to $97.3 \%$, showed good fits for all models. Still, considering the mean square error, where the lower value indicates the best fit to the data evaluated, the results were 13.1564 (Brody), 13.3421 (Von Bertalanffy), 13.4876 (Gompertz) and 13.6717 (Logistic). The results showed that Brody could be considered the model that best describes the growth rate up to 120 days old of Texel lambs.

Discussion: Compared to other studies, the average weights obtained in the experiment varied widely. This large variation can be explained by the used rearing system that might favor or not the performance of lambs. However, the average weaning weight obtained was similar to several studies in the literature, confirming the potential of Texel breed. This breed demonstrated to be capable to provide a precocious animal, with good growth results from the early developmental stage until the slaughtering age. Regarding the growth curves, the Brody model was the best fit for the estimated and observed weights. Moreover, the coefficient of determination indicated good fits for all models. However, an important aspect is the negative correlation between the $\mathrm{A}$ and $\mathrm{k}$ parameters, demonstrating that the higher the animal growth rate, the lower its asymptotic size.
\end{abstract}

Keywords: weight development, non-linear models, sheep. 


\section{INTRODUCTION}

Meat sheep farming is one of the activities with the highest growth potential among livestock activities in Brazil, which is related to the increasing lamb meat consumption [5]. However, to make this process economically feasible, it is necessary to use rapid growth breeds enabling the production of precocious sheep [12]. The meat breed Texel is known for being precious. Therefore, it is possible to obtain various data regarding the development of this breed, by measuring weights at certain ages, weight gains and other criteria aimed at determining the precocity and growth rates that are used as selection criteria in breeding programs [2].

Growth is one of the most important components when determining animal performance. Therefore, studies on the growth curves have increased in recent years. The growth curves allows analyzing sheep productive efficiency using the relationship between the weight and age to obtain descriptive information and predictions about growth development [7].

Thus, the growth curves can be used to describe animal growth over time, to establish appropriate feeding management and determine the optimum slaughtering age [13]. Thus, the study aimed to analyze which nonlinear models, including Brody, Gompertz, von Bertalanffy and Logistic, best fit the growth curve of Texel sheep.

\section{MATERIALS AND METHODS}

The experiment was conducted at the Capão da Onça School Farm (Fazenda Escola Capão da Onça, FESCON) of the Ponta Grossa State University located on $\mathrm{Km} 07$ of the Ponta Grossa - Itaiacoca road, in Ponta Grossa, PR, at $25^{\circ} 05^{\prime} 49^{\prime \prime} \mathrm{S}$ and $50^{\circ} 03^{\prime} 11^{\prime \prime} \mathrm{W}$, and $990 \mathrm{~m}$ altitude. The climate is subtropical humid mesothermal ( $\mathrm{Cfb}$ ), according to Köppen. The average temperatures are $13^{\circ} \mathrm{C}$ with the presence of frost in the winter and $21^{\circ} \mathrm{C}$, in the summer. The average rainfall ranges between 1600 and $1800 \mathrm{~mm}$ in the year and annual relative humidity, from 70 to $75 \%$ [1].

This experiment followed 42 Texel rams from birth to slaughter, between July 2013 and July 2014. Two lots of rams were weighed fortnightly during this year, and subsequently, the weights were averaged and analyzed. The weights were classified as follows, birth weight (BW), and weight at 15 days old (P15),
30 (P30), 45 (P45), 60 (P60), 75 (P75), 90 (P90), 105 (P105), and 120 days old (P120), considered the slaughtering weight. The rams were weighed in the morning after fasting for twelve hours.

The lambs were housed in a sheepfold with dirt soil and straw bedding, which was divided into five bays equipped with one feeding and two drinking troughs. The sheepfold had a movable mechanical scale (602 SM Model) ${ }^{1}$, with $300 \mathrm{~kg}$ capacity, where the sheep were weighed fortnightly. The lambs were confined from birth to slaughter, and fed concentrated feed (3\% of body weight) and corn silage (average $1.5 \mathrm{~kg} / \mathrm{animal} /$ day) 4 times a day. The concentrate consisted of ground corn, soybean meal, wheat bran, salt, ammonium chloride and vitamin mineral supplement. Furthermore, $1.5 \mathrm{~kg} / \mathrm{animal} /$ day of corn silage was available to the sheep daily.

The growth curves were determined using the following nonlinear models: Brody, $Y=A\left(1-B e^{-k t}\right)$; Von Bertalanffy, $Y=A\left(1-B e^{-k} t\right)^{3}$; Gompertz, $Y=A e^{B e^{\wedge}-k t}$; and logistic, $Y=A\left(1+e^{-k t}\right)^{-m}$. The parameters used in the growth curves were defined as: $(Y)$ slaughtering weight; (A) asymptotic weight indicating the average weight of the animal free of seasonal variations; $(\mathrm{k})$ growth rate at maturity indicating the growth speed; $(\mathrm{t})$ animal age; (b) constant related to the initial weight; and, (m) constant of curve shape, which determines the curve inflection point (point at which the animal changes from the inhibitory growth phase to reach a higher growth rate). The $\mathrm{B}$ constant is determined using the initial values of $Y$ and $t$.

Two criteria were used for selecting the model that best described the growth curves. The first, the mean square error (MSE), was calculated by dividing the sum of squared error by the number of observations, which is the maximum likelihood estimator of the residual variance, allowing to compare the MSE of different models since the numbers of parameters to be estimated are different. The second, the coefficient of determination $\left(\mathrm{R}^{2}\right)$ was calculated as the square of the correlation between the observed and estimated weights through a linear regression analysis considering the weight predicted by the nonlinear model as the dependent variable and the observed weight of the animal as the independent variable [16]. The parameters of the models were estimated by the Marquardt method modified by the statistical procedure NLIN of SAS $^{2}$ [14] (2009) using the convergence criterion $10^{-8}$. 


\section{RESULTS}

Table 1 shows the descriptive statistical results. The average birth weight was $4.02 \mathrm{~kg}$, which is considered high but not related to birth dystocia, as Texel sheep are medium to large animals. Birth weight is positively correlated with weights at older ages, therefore, higher birth weights, when not associated with dystocia, are positive for production at older ages [7]. Average weaning weight was $21.68 \mathrm{~kg}$, at 60 days of age. The slaughtering weight (120 days old) was $32.55 \mathrm{~kg}$, similar to the results reported in other studies that investigated wool sheep reared in intensive and semi - intensive systems.

The knowledge of the parameters used in the nonlinear models can assist in establishing specific feeding managements and defining the optimal slaughtering age. Table 2 shows the values of the parameters obtained from the nonlinear models. The values of A, which represents the estimated asymptotic weight, were in decreasing order 49.4777 (Brody), 38.4435 (Von Bertalanffy), 36.3539 (Gompertz) and 34.8503 (Logistic).

Table 1. Descriptive statistics of the weights.

\begin{tabular}{cccccc}
\hline Weights(days) & Average $(\mathrm{kg})$ & Minimun $(\mathrm{kg})$ & Maximun $(\mathrm{kg})$ & S. D. & C.V. $(\%)$ \\
\hline BW & 4.02 & 2.50 & 6.00 & 0.99 & 24.69 \\
W15 & 9.71 & 6.50 & 14.00 & 1.38 & 14.19 \\
W30 & 13.61 & 10.00 & 19.00 & 2.12 & 15.59 \\
W45 & 18.16 & 13.00 & 24.00 & 2.30 & 12.65 \\
W60 & 21.68 & 15.00 & 27.50 & 2.95 & 13.62 \\
W75 & 24.87 & 18.90 & 31.50 & 3.25 & 13.06 \\
W90 & 26.98 & 16.90 & 37.00 & 5.19 & 19.24 \\
W105 & 29.95 & 20.30 & 40.50 & 5.39 & 18.01 \\
W120 & 32.55 & 22.80 & 43.00 & 5.62 & 17.28 \\
\hline
\end{tabular}

S.D.: Standard Deviation; C.V.: Coefficient of Variation; BW: Birth Weight.

Table 2. Estimate of parameters (A), (B), (K), (m), mean square, coeficiente of determination in accordance with the models studied.

\begin{tabular}{ccccc}
\hline \multirow{2}{*}{ Parameter } & \multicolumn{4}{c}{ Models } \\
\cline { 2 - 5 } & Brody & Von Bertalanffy & Gompertz & Logístico \\
\hline (A) & 49.4777 & 38.4435 & 36.3539 & 34.8503 \\
$(\mathrm{~B})$ & 0.9151 & 0.4989 & 1.9536 & - \\
$(\mathrm{m})$ & 0.00805 & 0.0176 & 0.0222 & 0.0274 \\
Mean Square (MS) & - & - & - & 2.6776 \\
Coeficient of Determination $\left(\mathrm{R}^{2}\right)$ & 0.9736 & 13.3421 & 13.4876 & 13.6717 \\
\hline
\end{tabular}

A: Asymptotic weight; B: Initial weight; K: Growth rate; m: Responsible for curve shape.

The B constant, which indicates the ratio of asymptotic growth after birth, was higher in Gompertz (1.9536), followed by Brody (0.9151) and Von Bertalanffy (0.4989). Another important parameter is $\mathrm{k}$, animal maturity rate, which indicates growth rate to achieve asymptotic weight. The $\mathrm{k}$ values were highest for the Logistic model (0.0274), followed by Gompertz (0.0222), Von Bertalanffy (0.0176) and Brody (0.00805). The value of parameter $m$ is 2.6776 (Logistic model) and, like the B parameter, has no definite biological interpretation. However, they are important for determining the inflection point of the growth curve.

The coefficients of determination (Table 2) show that all models were a good fit to the data, with values close to $97.3 \%$. Furthermore, the MSE values were in increasing order, 13.1564 (Brody), 13.3421 (Von Bertalanffy), 13.4876 (Gompertz) and 13.6717 (Logistic); the lowest value indicates the best fit to the data. Figure 1 shows the model fittings to the data. 
(a)
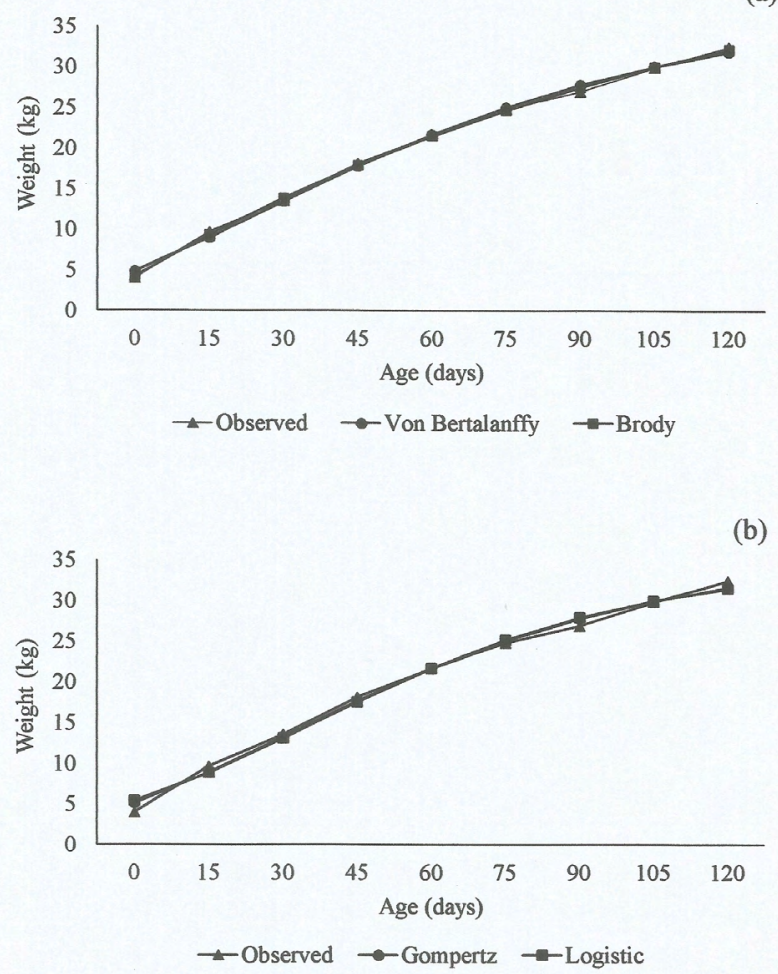

Figure 1. Curva de crescimento de ovinos machos da raça Texel, relacionadas aos modelos estatísticos Von Bertalanffy e Brody (a), e Gompertz e Logístico (b).

Another important aspect is the correlation between parameters, especially A and $\mathrm{k}$. The parameters $\mathrm{A}$ and $\mathrm{k}$ are common to all models and negatively correlated (Brody, -0.9900802; Von Bertalanffy, -0.9518102; Gompertz, -0.9247685; Logistic, -0.9042334), demonstrating that the higher the growth rate, the lower its asymptotic size.

\section{DISCUSSION}

The average birth weight was higher compared to the crossbred sheep Ile de France $\mathrm{x}$ Texel, which weighed $3.75 \mathrm{~kg}$ at birth, in semi-confined [11] system. However, confined Ile de France sheep displayed 4.58 $\mathrm{kg}$ average birthweight [9], which can be attributed to the large size of this breed.

The average weaning weight (60 days old) of Ile de France sheep in confinement, was 22.90 kg [4], similar to the weights observed in this study. This result demonstrates that the animals and the system adopted in this study had a good performance, which can be observed from the weaning, despite the higher birthweight and the characteristic larger size of Ile de France compared to Texel. This is important since better performances at weaning are associated with higher post- weaning weight gain and earlier slaughtering [9]. Santa Inez sheep raised in grazing system weighed $14.23 \mathrm{~kg}$ at weaning, 90 days old [17]. Therefore, suggesting that the poorer performance of Santa Inez may be possibly associated with the low quality of forages, and to the fact that this breed is considered late compared to wool sheep of fast muscle growth, such as the Texel breed. Still, Dorper x Santa Inez crossbred animals weighed an average of $17.72 \mathrm{~kg}$ at 84 days old, in extensive management [6]. The precocity of the sheep in this experiment can be explained by the intensive breeding system, and animal genetic potential, since they result from a long-term breeding program characterized by potentially high weight gain conducted in the region where the experiment took place.

The average weight at 120 days of age was similar to the results of other studies that investigated intensive and semi-intensive systems for rearing wool sheep. Some authors [10] reported average weight $32.54 \mathrm{~kg}$ at 124 days old, for animals weaned at 45 days old. These authors also reported slightly higher weight $32.80 \mathrm{~kg}$ at 116 days old for animals weaned at 60 days old. This 15-day difference in the weaning age may have favored the development of these sheep by improving adaptation and concentrate consumption. However, it is important to note that this difference in final weight may not be as advantageous as it seems because increasing feed consumption raises production costs. A study [3] with Texel sheep weaned at 64 days old in confinement, reported $3.33 \mathrm{~kg}$ average birth weight, $21.80 \mathrm{~kg}$ weaning weight, and $37.73 \mathrm{~kg}$ at 126 days old. These values are also consistent with the values measured in this study, showing that the confinement system provides outstanding performance and can be a good option for rearing sheep. Studies in the literature and the present study confirm the potential of wool breeds for rapid growth and weight gain, especially in the early stages of life.

Over the past few years, growth curves were used to analyze the growth rate of animals in the farm to improve their production systems [18]. Nonlinear methods are interesting alternatives because they allow the farmer to determine the model that best fits the growth behavior and development of the animals in the herd, so it becomes possible to predict or anticipate the most appropriate management system [4]. A growth curve study [13] has shown that non-linear models cannot solve the system of equations directly, as in 
the case of linear systems, since the resolution of the system depends on the estimation of the parameters themselves. Therefore, an iterative process is used to obtain estimates of the parameters, which begins with initial values assigned to the parameters to be estimated.

Table 2 shows the results for the parameter values; parameter A was highest in the Brody model and lowest in the Logistic model. The other models yielded intermediate values; however, the values are similar to those of the Logistic model. As seen in this study but with lower values, [7] compared non-linear models to describe the growth of Santa Inez x Texel sheep and found the highest parameter values for the Brody model (37.7) followed by Von Bertalanffy (32.2), Gompertz (30.6) and Logistic (29.14), demonstrating that the Texel breed tends to weigh more at maturity.

The parameter B represents the degree of sheep maturity at birth. Thus, high B values indicate low maturity at birth. The highest value for parameter B was obtained by the Gompertz model, followed by Brody and Von Bertalanffy. The graphs compare the growth rates, those estimated by the models and those observed. The results show that the Logistic and Gompertz models overestimated the birth weight while the Von Bertalanffy and Brody were closer to the actual birth weights.

The parameter $\mathrm{k}$ represents the mature rate and, for this reason, animals with high $\mathrm{k}$ values have early maturity. The highest value was estimated by the Logistic model compared to Gompertz, Von Bertalanffy and Brody. Comparing these results to those presented by [7], with Santa Inez x Texel crossbred animals, the highest $\mathrm{k}$ value was also estimated by the Logistic model and the lowest by the Brody model. Thus, it is possible to infer that the Logistic model tends to estimate higher $\mathrm{k}$ values in sheep reseaches; Besides that, the growth rates predicted in this study were considerably higher to those demonstrated by the same authors, representing the precocity of Texel sheep.

The parameter $m$ is seen only in the Logistic model. The estimated value was 2.53 , close to values reported for Morada Nova sheep [16]. This parameter determines the ratio of the asymptotic value, which is the inflection point of the established curve. Thus, the growth rates in this study tended to stabilize close to the animals assessed by the authors cited above.
According to the mean square error and coefficient of determination, Brody model was the best fit to describe the growth rate of Texel sheep up to 120 days old. A study with different races also concluded that Brody model was the best fit for the growth rate of sheep in different production systems [16,17]. Figure 1 illustrates the growth curves adjusted by the Brody and Von Bertalanffy models (a), and Logistic and Gompertz models (b), with the observed average weights. According to the growth rate estimates and the observed data, the growth curve given by the model is similar to growth curve during the 120 days, showing that the weights estimated by the models are very close to those observed, demonstrating the good fit of the model.

All models show a decreasing growth rate after the 60th day, however, albeit less pronounced, weight gain continues until 120 days old. This result can be interpreted not only as a decrease in bone and muscle growth but also as a physiological response to weaning. The growth curve has a short rise after 75 days that can be interpreted as animal adaptation response to the new nutritional system [9]. The fitting of weight-age data using growth rate models is a key tool to plan and manage animal production because it meets the desired requirements of sheep producers that want animals with proper weight and high carcass yield in a short period [15].

The correlation between parameters A and $\mathrm{k}$ was highly negative for all models. This indicates that animals that have high growth rate, tend to have lower asymptotic weights compared to those that have low growth rates, corroborating the results of several authors $[7,13]$. However, the more precocious the animals, the sooner it may be slaughtered, regardless of the possibility of reaching a slightly higher slaughtering weight [8]. It is noteworthy that the correlations between the other parameters were not displayed because they did not result in a significant effect.

\section{CONCLUSION}

All models demonstrated good fit for the growth curve, especially the Body model, due to the high coefficient of determination and low residual mean square. Considering this model in predicting the growth of Texel male lambs should facilitate the adequacy of nutritional management and set the best goals of animal selection. 
MANUFACTURERS

${ }^{1}$ Balanças Açores. Cambé, PR, Brazil.

${ }^{2}$ SAS: Analytics, Business Intelligence and Data Management. Cary, NC, USA.

Ethical approval. This experiment was approved and performed under the guidelines of Ethics Committee in Animal Use
(CEUA) of the Ponta Grossa State University (UEPG), according to statement $\mathrm{n}^{\circ} 020 / 2014$, in accordance to the regulations of the Brazilian Collegiate of Animal Experimentation (COBEA).

Declaration of Interest. The authors report no conflicts of interest. The authors alone are responsible for the content and writing of the paper.

\section{REFERENCES}

1 Bernardes L.R.M. 1998. Determinação de regiões pluviometricamente homogêneas no estado do Paraná, através de técnicas de análise multivariada. 136f. São Paulo, SP. Tese (Doutorado em Engenharia de Transportes) - Programa de Pós-graduação em Engenharia de Transportes, Universidade de São Paulo.

2 Blasco A. \& Gomes E. 1993. A note on growth curves of rabbit lines selected on growth rote or litter size. Animal Research. 57: 332-334.

3 Carvalho S., Vergueiro A., Kieling R., Teixeira R.C., Pivato J., Vieiro R. \& Cruz A.N. 2005. Desempenho e características de carcaça de cordeiros da raça Texel, Suffolk e cruza Texel x Suffolk. Ciência Rural. 35(5): 1155-1160.

4 Falcão P.F., Pedrosa V.B., Moreira R.P., Sieklicki M.F., Rocha C.G., Santos I.C., Ferreira E.M. \& Martins A.S. 2015. Curvas de crescimento de cordeiros da raça Ile de France criados em confinamento. Revista Brasileira de Saúde e Produção Animal. 16: 377-386.

5 Geron L.J.V., Mexia A.A., Garcia J., Zeoula L.M., Garcia R.R.F \& Moura D.C.D. 2012. Desempenho de cordeiros em terminação suplementados com caroço de algodão (Gossypium hirsutum L.) e grão de milho moído (Zea mays L.). Archives of Veterinary Science. 17(4): 34-42.

6 Malhado C.H.M., Carneiro P.L.S., Affonso P.R.A.M., Souza Junior A.A.O. \& Sarmento J.L.R. 2009. The growth curves in Dorper cross sheep with local Brazilian breeds, Morada Nova, Rabo Largo and Santa Inês. Small Ruminant Research. 84(1-3): 16-21.

7 Malhado H.M., Carneiro P.L.S., Santos P.F., Azevedo D.M.M.R., Souza J.C. \& Afonso P.R.M. 2008. Curvas de crescimento em ovinos mestiços Santa Inês x Texel criados no sudoeste do Estado da Bahia. Revista Brasileira de Saúde e Produção Animal. 9(2): 210-218.

8 McManus C.H.M., Carneiro P.L.S., Fernandes L.A.C., Miranda R.M., Bernal F.E.M \& Santos N.R. 2003. Curvas de crescimento de ovinos Bergamácia criados no Distrito Federal. Revista Brasileira de Zootecnia. 32: 1207-1212.

9 Moreira R.P., Pedrosa V.B., Falcão P.F., Sieklicki M.F., Rocha C.G., Santos I.C., Ferreira E.M. \& Martins A.S. 2016. Curvas de crescimento de fêmeas da raça Ile de France criadas em confinamento. Semina: Ciências Agrárias. 37(1): 303-310.

10 Moreno G.M.B., Silva Sobrinho A.G., Rossi R.C., Perez H.L., Leão A.G., Zeola N.M.B.J. \& Souza Junior S.C. 2010. Desempenho e rendimentos de carcaça de cordeiros Ile de France desmamados com diferentes idades. Revista Brasileira de Saúde e Produção Animal. 11(4): 1105-1116.

11 Muller L., Pires C.C. \& Tonetto C.J. 2006. Efeito de desmame precoce em cordeiros cruza Ile de France x Texel no desempenho e nas características da carcaça. Revista Ciência Agronômica. 37(2): 241-245.

12 Pilar R.D.C., Peres J.R.O., Muniz J.A. \& Bressan M.C. 2013. Alometria dos cortes da carcaça, em cordeiros Merino Australiano e cruza Ile de France x Merino Australiano. Current Agricultural Science and Technology. 14(4): 91-101.

13 Sarmento J.L.R., Regazzi A.J., Souza W.H., Torres R.A., Breda F.C. \& Menezes G.R.O. 2006. Estudo da curva de crescimento de ovinos Santa Inês. Revista Brasileira de Zootecnia. 35(2): 435-442.

14 SAS. 2009. Institute Inc. Statistical Analysis System user's guide. Version 9.2 ed. Cary: SAS Institute, USA.

15 Silveira F.G., Silva F.F., Carneiro P.L.S., Malhado C.H.M. \& Muniz J.A. 2011. Análise de agrupamento na seleção de modelos de regressão não-lineares para curvas de crescimento de ovinos cruzados. Ciência Rural. 41(4): 692-698.

16 Souza L.A., Carneiro P.L.S., Malhado C.H.M., Paiva S.R., Caires D.N.E. \& Barreto D.L.F. 2011. Curvas de crescimento em ovinos da raça Morada Nova criados no Estado da Bahia. Revista Brasileira de Zootecnia. 40(8): 1700-1705.

17 Teixeira M.C., Vilarroel A.B., Pereira E.S., Oliveira S.M.P., Albuquerque I.A. \& Mizubuti I.Y. 2012. Curva de crescimento de cordeiros oriundos de três sistemas de produção na Região Nordeste do Brasil. Semina: Ciências Agrárias. 33(5): 2011-2018.

18 Zadeh N.G.H. 2015. Modeling the growth curve of Iranian Shall sheep using non-linear growth models. Small Ruminant Research. 130: 60-66. 